more like theological knowledge than is commonly recognized. For instance, C. W. Francis Everitt, also of Stanford, points out the similarities in being dependent on a community and dealing with insoluble mysteries. A number of authors argue that scientific truths are too often revised to provide dogmatic refutations to religious claims. For instance, Christopher Moss points out that recognition of the subjective elements of science, conditioned by social circumstances have tended to desecralize science. Knowledge of God, Moss adds positively, has the moral seriousness of justice at its core.

Arguments for free will versus a materialistic determinism provide the most recurrent theme. Several authors suggest (though one dissents) that indeterminacy in quantum mechanics has a bearing on the question of free will. Statistician, D. J. Bartholomew, in summarizing his study, 'The God of

\section{Heroines of science}

\section{Janet Browne}

The Sclentific Lady: A Soclal History of Women's Scientific Interests, 15201918. By Patricia Phillips. Weidenfeld and Nicolson: 1990. Pp.279. £25, \$35.

THE presence - or more usually, the absence - of women in science has been the focus of much concern during the last decade or so. Academics and teachers go out of their way to encourage female pupils to consider a career in the subject, perhaps explaining that equal opportunities, though not perfect, have never been better: Victorian mores, they say, have passed at last. The Scientific Lady will therefore come as something of a surprise. The central theme of Patricia Phillips's book is that women's scientific activities were at their zenith during the eighteenth and nineteenth centuries and have steadily deteriorated since. Science, it is claimed, has not opened its doors willingly to women since the Taunton Commission of 1864-8.

According to Phillips, the first recognizably modern science as formulated in the seventeenth century was a low-status activity: natural philosophers were thought to be little more than artisans, their experiments requiring mechanical skills, their theories depending on physical demonstrations of effects. By contrast, the study of classics and the ancients were the highest point of intellectual life. Where women would only rarely aspire to studying Latin and Greek at that time (although some discussed by Phillips plainly did), the low status of science made it more permeable to female enthusiasts. Women like Mary Astell, Marie de Gourney and Margaret Cavendish (Duchess of Newcastle) found it possible to create a niche for themselves and worked hard in the field.
Chance', provides some ingenious additional arguments. For instance, he suggests that randomness is not incompatible with design because there are still highly probable aggregates. Moreover, a 'random search' may be an efficient way for a mind to operate, although allowing room for the free will. Sir John Eccles argues that demonstrable influences of minds on brains substantiates free will.

Books on the beliefs of scientists constitute a venerable genre to which this one is a worthy contribution. The essential message of this volume is that science is not legitimately an obstacle to religious belief. Perhaps now we need a sequel, Can Humanists Believe?'

George M. Marsden is in the Department of History, University of California at Berkeley, Berkeley, California 94720, USA.

With the great social changes of the eighteenth century there came a popularization of science among the European gentry which further stimulated female participation in scientific activities. This was the age in which Caroline Herschel studied astronomy, women wrote children's textbooks, and Aphra Behn translated Fontanelle's influential conversations into English. "Pray Sir," said one of Fontanelle's heroines, "leave Adorers alone, and let us speak of the Sun." The way women took over the media of science is an important aspect of the wider cultural context of the eighteenth century and is well laid out here. In particular, one little-known facet of the diffusion of science among women is brought to light by Phillips: printed diaries of the period seem to have sometimes included scientific questions expressly intended for female readers (perhaps a precursor to the Christmas quiz). The answers were promised in the next year's issue. A series of manuscript letters to the publishers conveying the answers well in advance shows just how educated some of these ordinary, otherwise unknown women were.

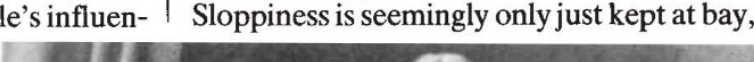

Equally welcome are the (too brief) discussions of the careers of significant figures like Augusta Ada Lovelace, Mary Somerville and Elizabeth Garrett Anderson. The thrust of these later chapters is the proposal that as science became more prestigious - and as emphasis on a classical education waned men pushed women out of their former niche. Once science was transformed into an important profession women's participation dramatically decreased.

Phillips's argument is a powerful one that bears careful attention, although some of her sweeping judgements may seem unlikely to professional historians of science and a few aspects surely overemphasized for effect. It is hard to think of Sir Isaac Newton as a rude mechanical, for example, although this could apply to Robert Hooke. More could have been said about French salons in which intellectual women reigned supreme. How odd not to find Florence Nightingale somewhere in the text: her impact on nineteenth century women and on culture at large cannot just be ignored. The analysis is furthermore predominantly confined to European ladies of high social standing. Chapters dance about through the centuries and on two or three occasions appear to contradict themselves. Sloppiness is seemingly only just kept at bay,

By the nineteenth century, women had carved a capacious niche for themselves, although Phillips seems rather to overstate the case with headlines like "The female science student was a familiar sight." Nevertheless, she is right to emphasize the diverse and often ignored functions taken up during that period. It is good to have attention drawn to the great numbers of women who listened to Humphry Davy and Michael Faraday lecture on their researches at the Royal Institution: fashionable occasions though these were, the audience was primarily there to learn.

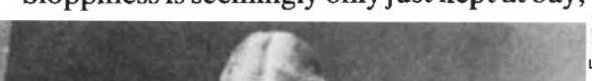

Janet Browne is at the Darwin Archive,
University Library, Cambridge CB3 9DR, UK.

ready to break out at any moment: the attractive dust-jacket, for instance, reads differently to the title page. But what this book misses in weight is balanced by a breezy, readable overview of the topic. Patricia Phillips is an anecdotal author with considerable style. It is social history with few pretensions and can be recommended to any general reader. 